\title{
16
}

\section{Exploring a Chairman of the Board's Construction of Organizational Reality: The Colruyt Case}

\section{Janson}

School of Business Administration

University of Missouri, St. Louis

St. Louis, Missouri 63121, USA

Tel: (314) 516-5846

E-mail: mjanson@umslvma.umsl.edu

\section{T. Guimaraes}

Tennessee Technological University

Cookville, Tennessee 38505, USA

Tel: (615) 372-3385

E-mail:TG5596@TNTECH.EDU

\section{A. Brown}

City University Business School

Frobisher Crescent, Barbican Center

London EC2Y 8HB, England

Tel: 440174778624

E-mail: A.P.Brown@CITY.AC.UK

\section{T. Taillieu}

Katholieke Universiteit Leuven

B3000 Leuven, Belgium

Tel: 3216326059

E-mail:Tharsi.Taillieu@psy.kuleuven.ac.be 


\begin{abstract}
A qualitative exploration of Colruyt, a Belgian company that evolved from a one-store enterprise into Belgium's third largest food retail chain comprising some 120 stores, is presented. The company is unique on several dimensions: its managerial structures and business processes, its use of information technology, and its views of company rights, duties, and obligations concerning customers, employees, creditors, and government. During this interview, Mr. Colruyt, ${ }^{1}$ Chairman of Colruyt's Supervisory Board, returns time and again to a single dominant idea: the use of information technology based communication to create new possibilities, organizational structures, and relationships among the firm and its employees, worker unions, customers, and suppliers. The qualitative exploration clarifies how societal, religious, historical, and linguistic beliefs unite to form a unique corporate environment. Because the contact time with the Chair of the Supervisory Board was limited to three hours, a qualitative approach was key to the success of an in-depth exploration of the company. Our analysis should be of interest to managers and academics who practice or study global business and business process reengineering.
\end{abstract}

\title{
1 INTRODUCTION
}

\subsection{Qualitative Research Approach}

This article presents the results of an interview-based study of Colruyt, a Belgian discount food chain, because it is an insightful example of qualitative research. According to Stake (1995), the essential difference between quantitative and qualitative research is that the former focuses on explanation and control whereas the latter centers on understanding complex interrelationships. Qualitative research has a longstanding tradition in diverse disciplines such as sociology, anthropology, public policy and education studies (Adler, Adler and Fontana 1987; Drummond 1994; Throngmorton 1993). However, the qualitative paradigm is not limited to the areas of study just listed. It is also the method of choice by many scholars for studying management and information systems phenomena (Aggarwal 1995; Thomas 1995). One of the most compelling qualitative studies we came across is Argyris' (1992) description of organizational learning.

The reason for selecting a qualitative approach was the limited time we had access to the company's chief executive officer. This left us no other tool than the semistructured interview. A close reading of many of the executive's position papers

${ }^{1} \mathrm{Mr}$. Colruyt was the recipient of the 1993 Belgian Business Man of the Year Award. 
dealing with social, political, and economic issues provided a solid basis for composing a set of well crafted interview questions. Furthermore, it was quite apparent from the aforementioned position papers that the executive very much thought in terms of broad philosophic, religious, economic, social, and political concepts. Our research put into perspective the company's chief executive's opinions by contrasting these with descriptive materials such as newspaper articles and company documents.

In the remainder of this the company's entry into the Belgian retail food industry in the 1960s is summarized and its adoption of informatization for corporate survival and success, its adaptation to a bilingual client base, programs for organizational and individual learning, use of a computer-based network for interpersonal communication, and its difficulties with several unions are described. In section 2, we discuss our qualitative research method. In section 3 , we present with a minimum of commentary our interview with Mr. Jo Colruyt. The interview is organized into four themes and is, for the most part, presented in chronological order. In section 4, we discuss and analyze several of the issues raised during the interview. Finally, in section 5, we present the implications of the interview for scholars and practitioners interested in global business.

Those seeking to improve their chances of success in today's global market would do well to consider the experiences, thoughts, and opinions of someone who has survived under turbulent economic, social, and cultural conditions. In fact, the company has thrived under conditions that are unmistakably postmodern, characterized as they are by ambiguity, paradox, discontinuity, fragmentation, and contradiction.

\subsection{Corporate Background}

Mr. Jo Colruyt presided over the evolution of his original one-store enterprise into a highly profitable retail food chain currently comprising some 120 stores located throughout Belgium. The company's success is particularly noteworthy considering local business conditions: stringent and wide-ranging governmental regulations, domination of the retail industry by well-established large food retailers, paper-thin profit margins, strict hierarchical managerial structures, and worker representation by unions of diverging ideologies with extensive influence over local and national government.

Several issues stand out with respect to the company's evolution into what is now the third largest Belgian retail food chain. First, Mr. Colruyt's philosophical views were essential to the company's thirty year long business success. His views, which were rooted in a natural bent toward matters of the spirit, were shaped by his preWorld War II formal training in the Belgian Catholic school system and by his postWorld II informal training in Marxism in Paris, France. As a result, before considering any action or strategy in his business, Colruyt focuses first on the cultural, behavioral, and communicative aspects. 
A second emerging issue was Colruyt's realization of the need for worker participation, decision making, and empowerment. To effect these objectives, he needed to initiate cultural change on two fronts: a culture of blindly following directives had to be transformed into a culture of personal initiative, risk taking, and decision making; and relations with the union had to be managed by discourse attuned to the union's ideological persuasion.

A further example of his need to consider culture before embarking on organizational change is the fact that Colruyt stores are located in the Flemish-speaking and French-speaking parts of Belgium. According to Mr. Colruyt, language is a determining factor in an individual's cultural, educational, and political experiences. Thus, even though language is needed to establish understanding and consensus between individuals, it also places limits on what can be expressed and communicated. To help bridge the gap between Flemish-speaking and French-speaking individuals, professionally trained translators ensure that company documents are available to employees in both languages.

Another example of Colruyt's attention to culture was the shift toward full worker participation. It was greatly helped when employees realized that their livelihood and the firm's success were inextricably linked. As the firm expanded, great care was taken to ensure that new hires would fit in. Once hired, a person would enroll in any of the company's extensive range of training programs that, among other things, introduced employees to the corporate culture, built interpersonal communication and decision making skills, and offered personal development opportunities.

A third issue of importance is the use of IT throughout the company to support individuals in their day-to-day activities. One of the most intriguing examples of the supportive role of IT is a company-wide computer-based system for the dissemination of information. First, the system captures and permanently stores on optical disk all information flows among employees and among employees and individuals outside the company. Second, the system functions as an organizational memory which enables information retrieval in ways that are exceedingly helpful to employees' task performance. About $85 \%$ of the information stored by the system is available to any company employee, including union stewards, which is indicative of the openness under which the company operates.

The firm's innovative business practices, including job rotation, job enlargement and enrichment, and the extensive informatization of all essential business activities were never approved by the unions. During the early 1980s, individuals connected with the unions published a research monograph accusing the company of "Taylorism." The authors of this monograph sought to show that informatization of all essential company activities led to a work atmosphere fundamentally at odds with individual freedom and dignity (Adele et al. 1984).

Many employees at all levels within Colruyt reacted angrily to the unions' allegations. Although a minority of employees agreed with the unions' allegations, a vast majority disagreed with the unions' charges. Employees' reactions, whether critical or supportive of the company, were published in book form and made available to the 
public. The incident taught the company a valuable lesson: no longer a minor player, the company could not continue to focus solely on its internal operations but also had to give considerable attention to its public relations.

\section{RESEARCH METHOD}

Our project is a qualitative interview-based attempt at uncovering and making explicit the conditions and individual actions surrounding the creation and development of entrepreneurial initiatives concerning Colruyt. Hartwick and Barki (1994) elaborated the different objectives of confirmatory and exploratory research approaches. Confirmatory research seeks support for hypotheses which have been formulated using an a priori theory. These hypotheses are subsequently tested using data from carefully controlled experimental studies.

Exploratory research proceeds differently than confirmatory studies. Rather than relying on large randomly selected samples, exploratory analysis employs small convenience samples. Instead of using test statistics based on assumed probability distributions, exploratory analysis for the most part uses tabular and graphical data displays and other techniques for probing the data flexibly (McNeil 1977).

Exploratory analysis represents a first contact with the data and aims to isolate data patterns and features, and to uncover, clarify, and simplify a data structure (Velleman and Hoaglin 1981). The data acquire meaning within the analyst's frame of reference because he or she searches for a satisfactory structure by confronting the data with a variety of alternative models (which is to say: the model follows the data). In this spirit, exploratory data analysis is defined by Benzecri (1980) as a "method that extracts structure from data."

Before scheduling the semi-structured interview with Mr. Colruyt, we first fixed our project's goals. The semi-structured interview sought information on 1) the age of the business and changing business conditions, 2) the company's managerial structure, 3 ) the number of employees and their contribution to achieving company objectives, 4) the nature of the business and competition and current and future markets, 5) Colruyt's business clients and the services delivered, 6) the company's operating philosophy, 7) the balance between providing clients a quality service and offering workers meaningful work while realizing adequate returns on investment and staying ahead of the competition, 8) the company's use and acquisition of standard and special software and hardware (e.g., word processing, spreadsheet, and data base), and 9) the company's use of information technology to serve clients and manage and maintain the company's information systems.

The three hour interview took place at the company's headquarters in the City of Halle, Belgium. The interview was conducted by two of the co-authors and audio taped in Flemish. The two co-authors are equally proficient in Flemish and English. After its transcription to written text, the interview was then translated into English by one of the bilingual authors and carefully checked for accuracy against the original 
Flemish version by the second bilingual author. Even though this article discusses the results of the interview with Mr. Colruyt, we did compare them with interviews conducted with other company personnel.

Sections of the interview's transcript are presented in chronological order. Only where absolutely necessary for clarity did we add explanations or rearrange words and sentences slightly. The interview is presented in six subsections including such topics as philosophy-driven management, instrumental rationality versus value rationality, worker empowerment and decision making, and information-driven strategy.

\section{THE INTERVIEW}

The opinions expressed during this interview cover a wide range of topics : the firm's relations with its customers, employees, unions, and governmental agencies. However, the leitmotif of the interview is how to fashion corporate strategies and modes of operating that are appropriate in light of contextual and cultural factors.

\subsection{Philosophy-Driven Management}

Mr. Colruyt is equally acquainted with the philosophical underpinnings of Christianity and Marxism. He attended Catholic schools until his eighteenth year. After leaving school, he lived in Paris, France from 1946 until 1947, where he joined a Communist cell organized by French university students. Concerning this important period in his life, Mr. Colruyt stated:

While adjusting to Parisian life I also confronted Marxist philosophy. I immersed myself in the movement and worked diligently to understand its philosophy. In essence, I learned a completely new language [with which to interpret my life world]. The experience changed my entire way of thinking.

The revelation of Stalin's excesses and the Communist takeover of Czechoslovakia in 1948 motivated Mr. Colruyt to reject Communism. During discussion with his Communist counterparts, Mr. Colruyt was impressed by the intense rationality of the debates. He was equally impressed by the deep-felt need on the part of his Communist counterparts for human contact.

Mr. Colruyt further remarked that the Communist debating style took on additional importance when later in his career he was forced to confront members of the Communist union. He stated:

During a fifteen-year period I had employees who were Marxist union members. I was able to keep the discussion with these employees going because I placed it in the context of Marxist ideology. 
Later during the interview, Mr. Colruyt returned to the important task for both the company and the union to communicate with employees. In response to the question concerning communication with employees, Mr. Colruyt said:

The company should keep the communication channels to the employees firmly in hand. Of course the unions should do likewise. But the unions should never get the exclusive right to communicating with the employees. As a company, you're lost if that were to occur! That is exactly what happened in the [Belgian] steel industry. Upper management started to feel superior vis-à-vis the working masses. The result: working people were informed solely by the unions. It was the deathblow for the steel industry, a real catastrophe!

Summarizing, we note that Mr. Colruyt's emphasis on communication, his interest in the workers' life world, and his penchant for rationality arose from his in-depth exposure to Roman Catholic and Marxist philosophical thought. Mr. Colruyt's remarks concerning the need for human contact expressed by his Communist counterparts foreshadow his later advice to temper rationality with a healthy dose of human emotion. Later during this interview, Mr. Colruyt returned to this topic.

\subsection{Instrumental Rationality Versus Value Rationality}

At different times during the interview, Mr. Colruyt often returned to the need for balancing rationality with emotionality. It clearly is an issue which holds his attention. Therefore, we followed up with the following questions:

M.J.: "You mentioned the rational aspect of Marxism. Would you say some more about rationality?"

J.C.: "I believe in launching and testing hypotheses and I view these as the only way to gain understanding. Hypotheses used to be formed by single individuals. Today, we need collective hypotheses which are created by groups consisting of twenty, fifty, or a hundred individuals. However, there are dangers associated with group hypotheses. Initial business success based on a collective hypothesis can turn into failure when the underlying assumptions no longer hold. Consider the unions: they have operated with the same hypothesis for fifty years. In today's world, that old hypothesis has lost much of its validity."

T.T.: "How do you debunk outworn collective hypotheses in the Colruyt organization?"

J.C.: "[You do that] in an atmosphere of open and frank discussion where there always exists the possibility that someone remarks, 'We have always analyzed this problem one way, how about looking at it differently?' The group builds a new Gestalt and suddenly one has two, three new hypotheses with which to interpret a situation. I feel most comfortable with three hypotheses; [because] that creates freedom, and freedom creates choice." 
T.T.: "Marius Janson and I had a discussion yesterday on why you speak in terms of Marxist and other philosophies. Is it because you need a framework for making matters clear to others?"

J.C.: "Humans make sense of their world through abstract models; without these, reality is too complicated. [Similarly], to understand society one needs multiple models - economic theory, social theory, capitalism, Marxism, Maoism, and so on. I think these [philosophical systems] embody a collective intelligence which is activated by open and frank communication. Communication among individuals occurs at meetings, on the telephone, and by using Colruyt's computer-supported system for information dissemination (ISID). They are all keys to company success.

"Many individuals also learn to appreciate that multiple models imply freedom of choice. I'll demonstrate this point with a practical example - I attend steering committee meetings where teams present [their] modeling results. These presentations are first class, naturally. [But] to make decisions I need to shake up the assumptions that underlie the model. In fact I regard coming up with alternative assumptions is one of the very few talents that I have. The team may respond with 'Yes but these new assumptions invalidate our modeling results.' I ask the team to rework the problem using these new modeling assumptions. Then, after comparing the results of both models, I often suggest a third model. Well, you understand the team's reaction. . . what misfortune befell us with a boss like that! Changing assumptions does create ambiguity which makes some individuals very anxious. I try to reassure that anxious person by telling him that he has done a fine and marvelous piece of work. However, and this time just for the fun of it, let's reevaluate the problem using a different hypothesis. Frequently, the idea of being playful is sufficient to bring someone around and convince him that his professional prestige is not questioned. Well, at times even [the playful aspect] does not work."

In summary, Mr. Colruyt maintains that rational decision making is essential to the success of the business. However, rationality in isolation is insufficient; decision makers have to also consider human emotion and intuition. More importantly, $\mathrm{Mr}$. Colruyt suggested a way to balance rationality with emotionality by making available to employees a wide range of company-sponsored seminars which focus on group dynamics, social and communication skills, assertiveness training, and so on.

Attending company-offered seminars raises the important issue of personal freedom because, even though the company does not force anyone to sign up for seminars against his will, every-day interaction with his colleagues who do attend seminars does place the non-attendee at a distinct disadvantage. In other words, it is debatable whether one can deal with emotionality in a seminar without also infringing on an employee's basic right to privacy.

The objective of these seminars is to enhance the individual's capacity for creating satisfactory interpersonal relations and achieving higher degrees of self-actualization. 
The seminars focus on personal issues such as: Who am I? How do I interact with myself and others? In the words of Mr. Colruyt the seminars are not "American style," which is to say that their objective is not to create "winners."

The above paragraphs reveal that the Colruyt company seriously attempts to avoid invading the employees privacy but reaches this goal only partially. In fact, Mr. Colruyt concluded that inasmuch as employees change as a result of attending the seminars, the organization has to change as well:

[A] person has to participate in a very real way, or else the individual is placed on the sidelines; or even worse - he is singled out or rejected! A nonparticipative individual gets run underfoot by a competitive environment. I would say that it is difficult for me to be definitive on this score. It strikes me that survey-based studies are needed to get a clearer insight into this issue.

As mentioned earlier, both rationality and emotionality are needed for decision making. Mr. Colruyt maintains that to do so calls for a feeling for humor to place situations in perspective. If someone during a decision-making meeting gets stressed out, much can be done with humor. This is exactly why sensitivity, assertiveness, and gestalt training are important. On the other hand, there are situations where all the sensitivity in the world just is inadequate; situations exist where it is necessary to pull out one's knife and ask "Well, what about it?"

\subsection{Worker Empowerment and Decision Making}

Earlier in the interview, Mr. Colruyt stressed balancing rationality and emotionality during decision making. During the ensuing questioning it became clear that the company has experimented without much success with several alternatives, such as the conflict and consensus approaches to decision making. Eventually the company settled on the following decision making rules:

1) Decisions are always made by a single individual.

2) The chair schedules the meeting. Meetings start and adjourn on time.

3) Decisions are never made during a meeting.

It should be stressed that decisions are always made by a single individual. The company has no faith in decision making by group consensus because these are always compromises and, according to Mr. Colruyt, have all the makings of a catastrophe! Throughout a meeting, the chair stays focused on "Is it necessary to make a decision? If so who will make that decision?" This could be the chair; however, it is also possible that someone else volunteers to take on the decision making responsibility. Decisions are never made during a meeting, because that would preclude careful contemplation.

Furthermore, all the affected individuals are informed of a decision before it is implemented. In other words, there is a grace period which enables feedback. Decisions that meet with adverse reactions are reconsidered and, where necessary, revised. When we discussed decision making, Mr. Colruyt returned to the topic of 
multiple models to represent reality. In this context, he commented on the company's decision making policy:

Multiple models - yes I think that is the reality! Experience taught us that these [aforementioned] procedures are in tune with the mentality of the Flemish here in Brabant. You should take these regional differences into account. The procedures may not be in tune with the mentality of people in other regions of Belgium. In one region, decision making takes the form of a parliamentary debate. Individuals first stake out their positions during lengthy discussions which focus on individual principles. Stating one's principles, it is important! Only after that do we get around to considering the decision needed. It goes without saying that all this lengthens the decision making period.

This quote introduces an additional difficulty: decision making in a bilingual and multi-cultural environment. The two languages do cause problems because, according to Mr. Colruyt, language and words function as models. A concept represented in Flemish can be replaced by its French counterpart; yet that is not sufficient. It is of foremost importance to consider the nuances and shades of meaning which reflect upbringing, education, culture, and politics - and this is a job for language experts.

During meetings, each employee has the right to speak his native tongue and professional translators are present in cases where meeting attendees are not bilingual. Moreover, each memo written in Flemish is translated into French and vice versa. As a minimum requirement, members of upper management have to understand, but need not speak, Flemish and French.

Finally, we summarized the interview with this question:

M.J: "Mr. Colruyt, throughout the interview we returned time-and-again to: 1) open communication in all directions and accessible to all employees, 2) decisions are made by a single individual, and 3) any form of communication is stored in the company's information system for information dissemination. As a result, it seems to me, little room exists for defensive or offensive maneuvering such as posturing, deception, or any other form of molding reality. Yet in day-to-day situations such strategies seem necessary or, at any rate, are used by many. How does one motivate individuals not to use these ingrained ways of dealing with the day-to-day activities of getting along with life?"

While answering this question $\mathrm{Mr}$. Colruyt retorted:

Not to use these strategies? They might still be used! I have discussed matters from my point of view. Is what I told you the "reality"? It is no more than my model of the Colruyt organization. I stand behind my views, but I have no idea how other Colruyt members model their reality. Do you grasp the point - you must not assume that I know the organization! 


\subsection{Information-Driven Strategy}

What sets the Colruyt Company apart from its competitors is a focus on informatization. Mr. Colruyt stated:

We started with one discount store in 1965 with the deliberate adoption of information technology. Our thinking: the eventual arrival of large computers is a certainty and we therefore should organize the entire sales function around the computer. Using information technology in all business aspects required corporate structures that were based on a totally new business rationale and this made us different from our competitors who inserted information technology into already existing organizational structures where it then met with serious resistance if not outright hostility. Information technology in 1965 meant an IBM 360-20 in our headquarters and a tabulating machine in the store. Yet, even this primitive technology had important business consequences for employee selection, customer service, and product assortment. First, the employee we needed did not fit the mold of the traditional lady at the store's checkout because that person would be unable to work with the computer. Second, the tabulating machine at the checkout station made it possible to provide the customer a unique service: a detailed description of his or her purchases. Third, relying on information technology excluded certain products from our assortment - even today we do not sell items to which we cannot affix a bar code. Well, again, we were and still are different from our competition because we organized our business around information technology right from the start.

While continuing on this topic, Mr. Colruyt mentioned further that the company has an information technology supported contract with the customer: to be less expensive than its competition, under all circumstances and on every sales item. To this end, the company maintains a centrally located database on the pricing policies and promotional campaigns of every competitor located within a twenty mile radius of each of the 120 Colruyt stores.

What makes all this a reality is the large computer software application that Colruyt's MIS department has developed and implemented. It is maintained by twenty employees who track pricing policies and special sales promotion of the competition. The contract with the customer has important business consequences: our prices are not cost driven, they reflect the pricing policies of the competition. If the company can no longer beat the competition on price while making a profit, it drops the item from its assortment. Before taking this step, though, the suppliers are presented with an option: lower the price or lose Colruyt as a customer.

To keep software development costs down, the company starts most informatization projects at the request of the user - a checkout clerk, a district manager, or a store manager. The user describes how the information system will improve his job performance, calculates the system's contribution to the company's bottom line, estimates 
its development and annual system maintenance expenses, and specifies the financial resources he or she is willing to contribute toward the system's development. This request is then submitted to a steering committee comprising high level managers, end users, and information specialists.

For example, a marketing manager's request for an information system to help mount a publicity campaign is submitted together with a clear and straightforward cost-benefit analysis. The steering committee would find it difficult to reject a request for an information system that shows a positive cost-benefit analysis. The only concern left here is the believability of the cost-benefit figures. Ultimately, this issue is resolved by judging the reliability of the person behind the estimates. One can always determine a person's reliability by checking estimates for previous software projects.

The important implication of this method is the shift from centralized to decentralized decision making concerning informatization projects while retaining some measure of upper management control. However, Mr. Colruyt further stated that upper management can and, indeed, should delegate decision making to the lowest possible level. But upper management cannot and should not delegate accountability for the company's resource expenditures.

\section{DISCUSSION}

\subsection{Social Theology}

While Belgium has been at the center of social, economic, intellectual, and religious developments in Western Europe, it also has often been invaded by foreign armies and ruled by foreign governments. These experiences combined with certain ideas promulgated by the Catholic Church have profoundly affected the way Belgians view the issues discussed in this interview. Toward the end of the nineteenth century, Pope Leo XIII issued his Rerum Novarum encyclical letter (Newman 1979). In this pastoral letter, which was a direct response to issues raised by socialism, the Pope threw his support behind the emergent Catholic social movement.

The encyclical dealt with five topics: the right to private property, the role of the Church in social affairs, social action by the Church, responsibilities of the state, and the right of workers to form voluntary associations such as unions (Newman 1979). First, the encyclical supported the right to private property. Second, the Church concluded that without its active involvement no solution to the social questions posed by socialism would be possible. Third, the Church resolved that its care for man would include his earthly condition as well as his fate in the hereafter. Fourth, the Church rejected laissez faire economics and held the state responsible for protecting private property, regulating working conditions, and guaranteeing workers a fair and living wage. Finally, the Church accorded workers the right to voluntary associa- 
tion such as unions and Church societies became preoccupied with social action (Harte 1979).

The encyclical stressed rights as well as obligations; the Church admonished the employer to pay a living wage, respect the worker's human dignity, and to promote the worker's physical and moral welfare. Furthermore, the Church suggested that the employer temper rationality with charity by ensuring job security in the face of short periods of seasonally caused unemployment (Lowrey 1979). The encyclical counseled the worker to fulfill his obligations agreed to in the work contract. The worker is to refrain from idling on the job, coming late, leaving early, and committing similar unlawful acts. The Pope's (Giordani 1979) interest in labor relations emanates from the sanctified character of work: "Since work is the God-ordained means of man's subsistence, man has both the duty and the right to work."

The encyclical Rerum Novarum would have little effect on day-to-day work life were it not for the great influence that the Catholic Church has over large segments of Belgium's social life. In 1963, more than $80 \%$ of Belgian youths who had joined organizations were members of Catholic ones and $25 \%$ of Flemish business leaders belonged to the Catholic Association of Business Owners (Dierickx 1979). In 1963, the Christian Unions had over 800,000 members, whereas in the case of the Socialist Union the count was 700,000. Moreover, a 1984 survey by Harding and Phillips found that $72 \%$ of the Belgian population are Roman Catholic. These numbers show that, even today, Catholic ideas are at the center of cultural life in Belgium.

We think that several company policies at Colruyt are linked to the ideas presented above. For instance, the company's promise to best any competitor on price is taken very seriously and the company goes to extremes to ensure that this commitment is met. The Catholic norm being invoked here is that a promise should be kept. Another example is that it is standard practice for employees to do more than one job. For example, checkout clerks also restock shelves and upper level managers work their way up from the shop floor. Extensive job rotation and multiple work assignments indicate that any type of work has intrinsic value and fosters mutual respect among the employees.

\subsection{Social Thought}

If it can be assumed that both Colruyt and traditional food retailers are under the sway of identical religious, social democratic, and Marxist influences, then any differences between Colruyt and traditional food retailers arise as a result of the dissimilar interactions between the respective retail organizations and the sociocultural environment.

Tables 1, 2, and 3 present the most noteworthy differences between the two major food retail chain types for three categories: service, labor, and ideology. First, extensive informatization of all aspects of the company's activities enables Colruyt to offer customers products in prepackaged, easy to use quantities at significantly lower costs than any competing store thanks to a vast up-to-date and store-by-store 
computerized database (Table 1). Furthermore, the high degree of informatization of all sales activities enables daily reshelving of all Colruyt stores and leads to further reductions in inventory, spoilage, and transportation expenses.

Table 1 Customer Service.

\begin{tabular}{|c|c|}
\hline Traditional Supermarket & Colruyt Discount Supermarket \\
\hline $\begin{array}{l}\text { Wide product assortment of- } \\
\text { fered in standard package sizes. } \\
\text { Inventory is replenished period- } \\
\text { ically. } \\
\text { - Inventory is supply driven. } \\
\text { - Stockouts are frequent. }\end{array}$ & $\begin{array}{l}\text { - Extremely wide product assortment offered at low } \\
\text { cost and in many different package sizes. } \\
\text { - Inventory is replenished daily. } \\
\text { - Inventory is demand driven using historical cus- } \\
\text { tomer purchasing figures. } \\
\text { - Stockouts are rare. }\end{array}$ \\
\hline $\begin{array}{l}\text { Esthetically pleasing store inte- } \\
\text { rior. } \\
\text { The intended message - a } \\
\text { pleasing store interior corre- } \\
\text { sponds to quality products. }\end{array}$ & $\begin{array}{l}\text { - Sober store interior lacking any but the most ba- } \\
\text { sic architectural features. } \\
\text { - The intended message - a sober store interior en- } \\
\text { ables low prices. }\end{array}$ \\
\hline $\begin{array}{l}\text { - Customer assistance is limited } \\
\text { to friendly service at the check- } \\
\text { out. } \\
\text { Average to long customer wait- } \\
\text { ing times are the rule. }\end{array}$ & $\begin{array}{l}\text { - Clients receive assistance throughout the store. } \\
\text { - Clients are assumed capable of making rational } \\
\text { and right amount of information - product con- } \\
\text { tents, product unit cost, and product preparation } \\
\text { guidelines. } \\
\text { - Short customer waiting times - during slack times } \\
\text { some checkout clerks restock shelves and during } \\
\text { busy times clerks assume checkout duties. }\end{array}$ \\
\hline $\begin{array}{l}\text { Cost reductions are achieved by } \\
\text { paying low wages, few benefits, } \\
\text { and by using many part-time } \\
\text { employees. }\end{array}$ & $\begin{array}{l}\text { - Cost reductions are achieved by employing few } \\
\text { but mainly full-time employees, by improving } \\
\text { employee and organizational efficiency and effec- } \\
\text { tiveness, and by bargaining for large-volume- } \\
\text { based product cost reductions. }\end{array}$ \\
\hline
\end{tabular}

Similarly, in Table 2 it is shown that, in contrast to its competition, Colruyt newhires are better educated, receive extensive on-the-job training, are empowered, handle significant levels of responsibilities, and perform multiple tasks. Full-time employee turnover and the number of part-time employees are extremely low. Low employee turnover in turn safeguards the investments in employee training and ensures a flexible work force with high levels of job familiarity and task preparedness. 
Table 2 Labor Structure.

\begin{tabular}{|c|c|}
\hline Traditional Supermarket & Colruyt Discount Supermarket \\
\hline $\begin{array}{l}\text { Employees focus on a single task } \\
\text { with a high degree of task demar- } \\
\text { cation. }\end{array}$ & $\begin{array}{l}\text { Employees focus on multiple tasks with a low } \\
\text { degree of task demarcation. }\end{array}$ \\
\hline $\begin{array}{l}\text { Employees have little formal edu- } \\
\text { cation. }\end{array}$ & $\begin{array}{l}\text { Employees have much formal education - } \\
\text { store clerks have high school diplomas, and } \\
\text { managers poses university degrees. }\end{array}$ \\
\hline $\begin{array}{l}\text { - Little on-the-job training. } \\
\text { - Little job rotation. }\end{array}$ & $\begin{array}{l}\text { - Much on-the-job training. } \\
\text { - An extensive company educational program- } \\
\text { course offerings focus on organizational and } \\
\text { inter-personal communication competencies. } \\
\text { - An extensive job rotation policy. }\end{array}$ \\
\hline $\begin{array}{l}\text { - Limited worker job responsibility. } \\
\text { - Limited worker empowerment. } \\
\text { ture with decision making located } \\
\text { at the top of the organization. }\end{array}$ & $\begin{array}{l}\text { Extensive worker responsibility - clerks per- } \\
\text { form multiple assignments ranging from } \\
\text { checkout duty to reshelving and cleaning the } \\
\text { store's interior. } \\
\text { - Extensive worker empowerment - clerks de- } \\
\text { cide when and how to perform their multiple } \\
\text { job responsibilities. } \\
\text { - A flat management structure with decision } \\
\text { making throughout the organization. }\end{array}$ \\
\hline $\begin{array}{l}\text { - Limited job security for full-time } \\
\text { employees. } \\
\text { - No job security for part-time } \\
\text { employees. } \\
\text { - High employee turnover. } \\
\text { - Homogeneous labor markets. }\end{array}$ & $\begin{array}{l}\text { - Much job security for full-time employees. } \\
\text { - Little employee turnover. } \\
\text { - Heterogeneous labor markets. }\end{array}$ \\
\hline
\end{tabular}

Perhaps the most interesting items in the ideological category of Table 3 are postmodernism and deconstruction. Postmodern life is a fractured experience and consists of a series of indeterminates. Furthermore, as Abrams (1988), Holman and Harmon (1992), Lyotard (1992), and Sarup (1989) point out, language itself is problematic and subversive.

During the interview, Mr. Colruyt turned to postmodern ideas and conceptualized language as a "model" and contemplated assigning various meanings to words. Mr. Colruyt, in effect, stated that translating a French word into a Flemish word is not just a matter of consulting a dictionary. He remarked that one's language is the result, among other things, of one's upbringing, education, culture, and political experiences (Cottom 1989). Furthermore, while discussing his attending steering committee meetings, Mr. Colruyt mentioned making problematic the analyses presented by 
working groups. He did so by experimenting with the hypotheses underlying the analyses. Reality is fundamentally altered by assuming different vantage points. By their reactions, the working group members reveal their extreme discomfort with this fundamental change in reality.

Table 3 Company Ideology.

\begin{tabular}{|c|c|}
\hline Traditional Supermarket & Colruyt Discount Supermarket \\
\hline $\begin{array}{l}\text { Modernism informs the company's ide- } \\
\text { ology - modernism is based on the con- } \\
\text { cepts of instrumental rationality and } \\
\text { value rationality. } \\
\text { Socialization of the individual into larger } \\
\text { group entities. }\end{array}$ & $\begin{array}{l}\text { Postmodenism informs the company's } \\
\text { ideology - postmodernism is based on } \\
\text { the questioning of the grand narratives. } \\
\text { - Attention is on the individual. }\end{array}$ \\
\hline $\begin{array}{l}\text { Fordism - mass production and mass } \\
\text { marketing of homogeneous products. } \\
\text { The aim is mass consumption of a lim- } \\
\text { ited assortment of products. }\end{array}$ & $\begin{array}{l}\text { Postfordism - small batch production of } \\
\text { many heterogeneous products and niche } \\
\text { marketing. } \\
\text { - The aim is individualized production and } \\
\text { selective consumption from among a } \\
\text { very large assortment of products. }\end{array}$ \\
\hline $\begin{array}{l}\text { Rigid organizational structures coupled } \\
\text { with top-down command structures and } \\
\text { bottom-up communicative structures. } \\
\text { The organizational structures are based } \\
\text { on bureaucratic concepts. } \\
\text { Employees mistrust management. }\end{array}$ & $\begin{array}{l}\text { - Flexible organizational structures couple } \\
\text { with networked command and net- } \\
\text { worked communicative structures. } \\
\text { - The organizational structures are based } \\
\text { on democratic concepts. } \\
\text { - Employees trust management. }\end{array}$ \\
\hline $\begin{array}{l}\text { - Planning - short term. } \\
\text { - Spatial centralization - product pricing } \\
\text { on system-wide basis. }\end{array}$ & $\begin{array}{l}\text { - Planning - long term. } \\
\text { - Spatial decentralization - product pric- } \\
\text { ing is determined on a store-by-store } \\
\text { basis. }\end{array}$ \\
\hline $\begin{array}{l}\text { Managerial decision making - consensus } \\
\text { seeking. } \\
\text { Managerial decision making - rational- } \\
\text { ism. }\end{array}$ & $\begin{array}{l}\text { - Managerial decision making - consent } \\
\text { seeking. } \\
\text { - Managerial decision making - } \\
\text { deconstructionalism. }\end{array}$ \\
\hline
\end{tabular}

Note also Mr. Colruyt's closing statement: "I stand behind my views, but I have no idea how other Colruyt members model their reality. Do you grasp the point - you must not assume that I know the organization!" The sentence invites others to structure reality totally differently. Yet, his comment "I stand behind my views" implies that these multiple fractured experiences are all legitimate.

Deconstruction is a philosophical development that rejects the notion of objective truth or structure (Culler 1983; Derrida 1976, 1978; Holman and Harmon 1992). Deconstruction, which was first applied in linguistics, is the basis of several recent 
developments in textual criticism, political science, management theory, and information systems (Beath and Orlilowsky 1994; Leitch 1983; Taylor 1986). A critical notion of deconstruction is that any system of thought can be made to dissolve by the application of the very assumptions that underlie it.

On the topic of company relations with the unions, Mr. Colruyt remarked that his intimate knowledge of Marxist thought enabled him to establish and maintain a meaningful discussion. Mr. Colruyt uses Marxist rationality to make problematic the position of union leaders. Furthermore, the Colruyt company uses its computer-based communication system to make its negotiations, discussions, and correspondence with the unions available to the rank and file. In effect, the company subverts the possibility of any union posturing by its direct, frank, and "in your face" communication practices.

\subsection{Informatization and Work Life}

The effect of informatization on work life is controversial, with some being overly positive and others overly pessimistic (Dunlop and Kling 1990). Rule and Attewell (1990) claim the desire to make human and organizational behavior more rational and predictable is a frequent motivation for informatization. However, as pointed out by Dunlop and Kling, increased levels of efficiency and rationality usually benefit the owners and the stakeholders in the organization. That is to say, the interests of the workers and other members of the organization are, at best, overlooked. It would be easy to view the informatization efforts at N.V. Colruyt in negative terms (Adele et al. 1984). Thus, for example, the checkout information system automatically records customer service-times. At the end of a clerk's shift, the information system ranks these data on customer service-time. The clerk is then informed of the three highest ranked service-times. It is easy to see that this practice could lead to grave abuse (Attewell 1990).

Early on in the interview, Mr. Colruyt remarked that he accepted the positive and the negative implications of information technology. He argues time and again for the worker's right to privacy. To avoid privacy abuses, these service-time figures are not available to the clerk's direct supervisor (i.e., the store manager). Data access is restricted to the district manager and then only averaged on a store-by-store basis.

In paradoxical fashion, the company's openness once gave rise to privacy abuses. In a company directive, Mr. Colruyt discussed the balance between openness and potential abuse. In response to unauthorized information leaking to the press, some board members argued for restricting access to the company's computer-based information system for information dissemination. Mr. Colruyt disagrees with restricting information access. Instead, he proposes training employees in responsible 
use of information. In fact, he suggests that the drawbacks of restricting information access outweigh the risk of unauthorized information use (Colruyt 1985).

Colruyt practices informatization in a very participatory manner. Requests for information systems most frequently originate and are funded at the user level. In fact, system requests are initiated at the lowest managerial levels of the company and then developed with user oversight. It would be no overstatement to claim that system development is based on emancipatory principles.

We think that emancipatory principles are indeed an important weapon in the hands of workers who stand up for their rights and exert a meaningful influence over their work life. Over a two year period, we spent some twenty hours observing Colruyt stores and were impressed by the open, candid, and assertive manner of personnel behavior and comportment. Not everyone appreciates the assertive corporate culture. According to one employee, assertiveness at times crosses the border into aggressiveness, arrogance, and guilt by public opinion. However, most employees consider assertiveness a favorable trait and several clerks disclosed that it is acquired and encouraged in company-sponsored seminars and in day-to-day experience. One clerk expressed it succinctly in untranslatable Flemish but which approximates the English equivalent of "You have to stick up for yourself."

\section{CONCLUSION}

Despite his claims to the contrary, our qualitative research illustrates that $\mathrm{Mr}$. Colruyt's ideas gave rise to an organization that is totally different from its competitors on several dimensions. As illustrated in Tables 1,2, and 3, these differences greatly impact customer service, the company's labor structure, and its ideology. We show how a nation's cultural and religious values, and its historical experience, impact a company's operating philosophy, organizational structure, decision making, informatization, and value adding activities.

Our project demonstrates how qualitative research is a valuable instrument for uncovering contextual factors that may help or hinder organizational success. Hence, our interview-based study should be of interest to managers who face the demanding task of guiding their firm toward success in the turbulent global market.

\section{ACKNOWLEDGMENT}

This research project was supported in part by the Center for International Studies and the Office of Research at the University of Missouri-St. Louis, St. Louis, Missoui, USA, and by the Work and Organization Research Center at the University of Tilburg, Tilburg, The Netherlands. 


\section{REFERENCES}

Abrams, M. H. (1988). A Glossary of Literary Terms. New York: Holt, Rinehart, and Winston.

Adele, B.; Martens, A.; Tordeur, G.; van der Smissen, E.; and van Muelenaer, G. (1984). Dossier Colruyt. Antwerp, Belgium: EPO.

Adler, P. A.; Adler, P.; and Fontana, A. (1987). "Everyday Life Sociology." In K. Plummer (Editor), Symbolic Interactionism: Foundations and History. Brookfield, Vermont: Edward Elgar, pp. 436-454.

Aggarwal, S. (1995). "Emerging Hard and Soft Technologies: Current Status, Issues and Implementation Problems." Omega, International Journal of Management Science, Volume 23, Number 1, pp. 323-339.

Argyris, C. (1992). On Organizational Learning. Cambridge, Massachusetts: Blackwell.

Attewell, P. (1990). "Big Brother and the Sweatshop: Computer Surveyance in the Automated Office." In C. Dunlop and R. Kling (Editors), Computerization and Controversy: Value Conflicts and Social Choices. Boston: Academic Press, pp. 236-256.

Beath, C., and Orlikowsky, J. (1994). "The Contradictory Structure of Systems Development Methodologies: Deconstructing the IS-User Relationship in Information Engineering." Information Systems Research, Volume 5, Number 4, pp. 350-399.

Benzecri, F. (1980). Data Analysis. Paris: Dunod.

Colruyt, J. (1985). "Information System for Information Dissemination and Confidentiality." In T. Penneman (Editor), There are no Gentlemen Here, Sir. Halle, Belgium: Druco, p. 238.

Cottom, D. (1989). Text and Culture. Minneapolis: University of Minnesota Press. Culler, J. (1983). On Deconstruction: Theory and Criticism after Structuralism. Ithaca, New York: Cornell University Press.

Derrida, J. (1976). Of Grammatology. Baltimore: Johns Hopkins University Press. Derrida, J. (1978). Writing and Difference. Chicago: Chicago University Press.

Dierickx, M. (1979). “Belgium.” In P. A. Resch (Editor), New Catholic Encyclopaedia. New YorkL McGraw Hill, Volume II, pp. 245-249.

Drummond, H. (1994). "Too Little Too Late: A Case Study of Escalation in Decision Making.” Organization Studies, Volume 15, Number 4, pp. 591-607.

Dunlop, C., and Kling, R. (1990). "The Dreams of Technological Utopianism." In C. Dunlop and R. Kling (Editors), Computerization and Controversy: Value Conflicts and Social Choices. Boston: Academic Press, pp. 14-30.

Giordiani, I. (1979). "In the Bible." In P. A. Resch (Editor), New Catholic Encyclopaedia. New York: McGraw Hill, Volume XIII, pp. 343-346.

Harding, S.; Phillips, D.; and Fogarty, M. (1984). Contrasting Values in Western Europe. New York: MacMillan. 
Harte, T. (1979). "Papal Social Thought.” In P. A. Resch (Editor), New Catholic Encyclopaedia. New York: McGraw Hill, Volume XIII, pp. 352-354.

Hartwick, J., and Barki, H. (1994). "Hypothesis Testing and Hypothesis Generating Research: An Example from the User Participation Literature." Information Systems Research, Volume 5, Number 4 (December), pp. 446-449.

Hofstede, G. (1980). "Motivation, Leadership, and Organization: Do American Theories Apply Abroad?" Organizational Dynamics, Volume 9, pp. 42-63.

Hofstede, G. (1991). Cultures and Organizations: Software of the Mind. New York: McGraw Hill.

Hofstede, G. (1993). "Cultural Constraints in Management Theories.” Academy of Management Executive, Volume 7, pp. 81-94.

Holman, C. H., and Harmon, W. (1992). A Handbook to Literature. New York: MacMillan.

Leitch, V. B. (1983). Deconstructive Criticism. New York: Columbia University Press.

Lowrey, D. (1979). “Moral Obligations of Employers.” In P. A. Resch (Editor), New Catholic Encyclopaedia. New York: McGraw Hill, Volume V, p. 328.

Lyotard, J. F. (1992). The Post-Modern Explained. Minneapolis: University of Minnesota Press.

McNeil, D. R. (1977). Interactive Data Analysis: A Practical Primer. New York: Wiley.

Newman, J. (1979). "Rerum Novarum.” In P. A. Resch (Editor), New Catholic Encyclopaedia. New York: McGraw Hill, Volume XII, p. 387.

Poole, M. (1986). Industrial Relations: Origins and Patterns of National Diversity. Boston: Rouledge \& Kegan Paul.

Rule, J., and Attewell, P. (1990). "What Do Computers Do?" In C. Dunlop and R. Kling (Editors), Computerization and Controversy: Value Conflicts and Social Choices. Boston: Academic Press, pp. 131-149.

Sarup, M. (1989). An Introductory Guide To Post-Structuralism and Post-Modernism. Athens, Georgia: University of Georgia Press.

Stake R. (1995). The Art of Case Study Research. Thousand Oaks, California: Sage Publishing.

Taylor, M. C. (1986). Deconstruction in Context: Literature and Philosophy. Chicago: University of Chicago Press.

Thomas, P. (1995). The Social and Interactional Dimensions of Human-Computer Interfaces. New York: University of Cambridge Press.

Throngmorton, J. A. (1993). "Survey Research as Rhetorical Trope: Electric Power Planning in Chicago." In F. Fischer and J. Forrester (Editors), The Argumentative Turn in Policy Analysis and Planning. Durham, North Carolina: Duke University Press, pp. 118-144.

Velleman, P., and Hoaglin, D. C. (1981). Applications, Basics, and Computing of Exploratory Data Analysis. Boston: Duxbury Press. 


\section{BIOGRAPHY}

Marius Janson is Associate Professor of Management Sciences and Information Systems and Fellow in the Center for International Studies at the University of Missouri, St. Louis. He received his Ph.D. from the University of Minnesota. His current research interests center on social and international issues of information systems use. His articles have appeared in Decision Sciences, Information and Management, Journal of Behaviour and Information Technology, Journal of Management Information Systems, and MIS Quarterly.

Tor Guimaraes is the director of the Institute for Technology Management and holder of the Jesse E. Owen Chair of Excellence at Tennessee Technological University. Tor has a Ph.D. from the University of Minnesota and an M.B.A. from California State University, Los Angeles. In descending chronological order, he was Professor and Department Chairman at St. Cloud State University, and Assistant Professor and Director of the MIS Certificate Program at Case Western Reserve University. $\mathrm{He}$ has been the keynote speaker at national and international meetings sponsored by organizations such as the Information Processing Society of Japan, Institute of Industrial Engineers, American Society for Quality Control, IEEE, ASM, and Sales and Marketing Executives. He has consulted with many leading organizations including TRW, American Greetings, AT\&T, IBM and the Department of Defense. With his partners throughout the world he has published over one hundred articles on technology management in leading journals.

Ann Brown is a graduate of the London School of Economics. She worked in the Central Operational Research Group of the British Steel Company before joining the City University Business School. She applied her early work on planning methods and investment appraisal to information systems before going on to develop a program of research on the subject of the management of IS/IT within organizations. She helped form the new group of practitioners and academics working in the subject of IS evaluation, being Chair for the first three European Conferences on the evaluation of IT, and Conference Chair for the Fourth European Conference of the evaluation of IT in 1997. Publications include journal papers, book and conference proceedings editorships, and short articles. Her current research is concerned with the impact of IS on organizational structure and work roles, and IS as a strategic resource.

Tharsi Taillieu is Professor of Organizational Psychology at the Catholic University of Leuven. He also teaches at the Tilburg Institute for Academic Studies, School of Management and Organization and School of Marketing, of Tilburg University where he worked for several years. He studied Industrial Psychology at the Catholic University of Leuven and received his Ph.D. from the Graduate School of Industrial Administration, Carnegie Mellon University. His current research concerns the nature of activities and work role of managers in settings where multiple parties collaborate in alliances and networks. 